\title{
Margaret McCartney: Stop relying on charity
}

\author{
Margaret McCartney general practitioner, Glasgow
}

In the past week three young people have come to my door, with lanyards and branded T shirts, asking me to pledge regular donations to charity. Each represented a big, national, medical charity, the kinds with marketing managers and campaign teams. I said no to each one, which prompted two of them to enter into sales pitches about how helping to set up a direct debit would "just take a minute." Both looked annoyed when, again, I said no thanks.

Doorstep selling is a good way to pressurise people - and a bad way for people to understand the potential recipients of their money. I want to give to charities in the most evidence based way possible: I want to support organisations without unjustifiably high administration costs, ones that act rationally and plan for the long term.

More fundamental problems, though, affect the current model of charity in the United Kingdom. Currently, charitable organisations compete with one another to attract donations. Animal charities receive more money than charities that support homeless people, disabled people, or older people. ${ }^{1}$ Giving money on the basis of a cause's popularity may mean that some groups with greater needs miss out.

The Roy Castle Lung Cancer Foundation’s income was $£ 4.8 \mathrm{~m}$ in $2013^{2}$; Breakthrough Breast Cancer raised $£ 16.3 \mathrm{~m} .{ }^{3}$ Yet $22 \%$ of the UK's deaths from cancer result from lung cancer, compared with $7 \%$ from breast cancer. ${ }^{4}$ Are we perhaps more reluctant to give to a charity for a disease many people associate with smoking?

Funding through charity cannot be guaranteed, because it depends on individual judgment. It seems wrong that vital needs - research, personal care, or support - are paid for in this way. Another example is hospices, which are usually funded only in part by the NHS, meaning that their availability depends on the generosity of the community. Surely, if we have evidence of a need for hospices or specialist nurses, their cost should be met by public funds.

Charitable donation is being used to fill gaps that should be filled through taxation. Surveys presented at the British
Sociological Association in 2013 found that the poorest 20\% of people gave $3.2 \%$ of their gross income to charity, compared with only $0.9 \%$ of gross income from the richest $20 \% .{ }^{56}$ In other words, proportionally, this system has the poorest people subsidising the richest.

Follow Margaret on Twitter, @mgtmccartney

Competing interests: I have read and understood the BMJ policy on declaration of interests and declare the following interests: I'm an NHS GP partner, with income partly dependent on Quality and Outcomes Framework points. I'm a part time undergraduate tutor at the University of Glasgow. I've written two books and earn from broadcast and written freelance journalism. I'm an unpaid patron of Healthwatch. I make a monthly donation to Keep Our NHS Public. I'm a member of Medact. I'm occasionally paid for time, travel, and accommodation to give talks or have locum fees paid to allow me to give talks but never for any drug or public relations company. I was elected to the national council of the Royal College of General Practitioners in 2013 and am chair of its standing group on overdiagnosis. I have invested a small amount of money in a social enterprise, Who Made Your Pants?

Provenance and peer review: Commissioned; not externally peer reviewed.

Charities Aid Foundation. UK Giving 2014. April 2015. www.cafonline.org/pdf/CAF\% 20UK\%20Giving-FINAL\%20-\%20web\%20enabled.pdf.

2 Roy Castle Lung Cancer Foundation. Report and financial statements for the year ended 31 December 2013. http://documents.roycastle.org/RCF2013.pdf.

3 Breakthrough Breast Cancer. Annual report and accounts 2012-2013. 2013. http://bit.ly/ 1 Hoe1Od.

4 Cancer Research UK. Cancer incidence and mortality in the UK. September 2014. http:/ /publications.cancerresearchuk.org/downloads/Product/CS_REPORT_TOP10INCMORT. pdf.

5 University of Manchester. Poor more generous than rich in recession, study shows. 3 April 2013. www.manchester.ac.uk/discover/news/article/?id=9782.

6 Li Y. The flow of soul: a sociological study of generosity in England and Wales 2001-2011. Forthcoming in: Li Y, ed. The handbook of research methods and applications on social capital. Edward Elgar Publishing, 2015.

Cite this as: BMJ 2015;350:h2034

๑๑ BMJ Publishing Group Ltd 2015 